\title{
12. SEISMIC VELOCITIES OF LEG 37 ROCKS AND THEIR GEOPHYSICAL IMPLICATIONS
}

\author{
Nikolas I. Christensen, Department of Geological Sciences and Graduate Program in Geophysics, \\ University of Washington, Seattle, Washington
}

\section{INTRODUCTION}

The interpretation of seismic refraction velocities in the oceanic crust is important in understanding the constitution of the crust and the history of ocean basins. Of critical importance for such interpretations are laboratory measurements at elevated pressures and temperatures on oceanic samples obtained by dredging and drilling. Recent ultrasonic studies of compressional and shear wave velocities in oceanic rocks dredged from fracture zones and ridge crests have proven valuable in understanding the composition of the oceanic crust (e.g., Barrett and Aumento, 1970; Christensen, 1970, 1972; Christensen and Shaw, 1970; Fox et al., 1973; Christensen and Salisbury, 1975). A large number of additional velocity measurements of igneous rocks, largely basalt, are given in several volumes of the Initial Reports of the Deep Sea Drilling Project. Of significance, especially for comparisons with velocities of Leg 37 samples, are the high pressure measurements of velocities in metagabbro, metadiabase, gabbro, and anorthositic gabbro obtained from Site 293 of Leg 31 (Christensen et al., 1975).

In this study velocities are reported to hydrostatic pressures of $10 \mathrm{kbar}$ at ambient temperature, for 13 samples obtained from Leg 37 drilling. Emphasis is placed on the elastic properties of the gabbroic and ultramafic rocks from Site 334, with the objective of understanding the geologic processes which were responsible for the emplacement of this rock suite at such shallow crustal depths.

\section{VELOCITY DATA AND ELASTIC CONSTANTS}

Velocities as a function of pressure and bulk densities are tabulated in Table 1. The travel times of the compressional and shear waves were measured by the pulse transmission technique using a mercury delay line (Birch, 1960). The velocities are estimated to be accurate to better than 1\% (Birch, 1960; Christensen and Shaw, 1970). All samples were water saturated prior to the measurements, and pore pressures were maintained at values lower than external pressures by placing a 100-mesh screen between the samples and copper jackets. The screening requires considerable time in the process of sample preparation; however, it is essential that water be allowed to drain from the pore spaces during the application of pressure.

Several samples studied to $10 \mathrm{kbar}$ were identical to those used for ship velocity measurements (Table 1). The core ends of Samples 332B-3-3, 100-103 cm, 333A$3-1,129-131 \mathrm{~cm}, 334-22-1,69-71 \mathrm{~cm}, 334-24-1,63-65$ $\mathrm{cm}$, and 335-11-1, 76-78 $\mathrm{cm}$ were relapped prior to our measurements, because they were found to deviate significantly from parallelism. In order to detect possible anisotropy, velocities were measured in two cores cut perpendicular to one another for Sample 33423-1, 135-144 cm.

In addition to velocities, several parameters are useful in describing elastic properties and interpreting composition from seismic refraction studies (e.g., Birch 1961; Christensen, 1972). These include the shear modulus or rigidity $(\mu)$, Lamés constant $(\lambda)$, the bulk modulus $(K)$, Young's modulus $(E)$, compressibility $(\beta)$, Poisson's ratio $(\sigma)$, and the seismic parameter $(\phi)$, defined as $K / \rho \pi$, where $\rho$ is density. Although there are several techniques for obtaining these constants, all can be calculated conveniently from $V_{p}, V_{s}$, and $\rho$ (Birch, 1961). Values of these parameters at selected pressures are given in Table 2. Velocities and densities used in the calculations were corrected for compression using an iterative routine and the dynamically determined compressibilities.

\section{VELOCITY-DENSITY RELATIONS}

Tendencies for compressional and shear velocities to increase with density have been amply demonstrated (e.g., Birch, 1960; Simmons, 1964) and simple correlations often have been presented for oceanic basalts (e.g., Christensen and Shaw, 1970; Christensen and Salisbury, 1973). With more extensive studies of a wider variety of oceanic rocks now available, it is clear that proportionality holds only for specific rock types (Christensen and Salisbury, 1975). For example, compressional wave velocities of serpentinized oceanic rocks have been found to be approximately $8 \%$ higher than basalts of similar density, whereas shear velocities for both rocks types are generally similar for a given density. Thus compressional wave velocity-density relations and many of the elastic constants of serpentinized rocks differ from those of basalts. In particular, the ratios of $V_{p}$ to $V_{s}$ and hence Poisson's ratios of serpentinized oceanic rocks are relatively high (Christensen, 1972). Poisson's ratios of 0.35 (Table 2) for the two partially serpentinized rocks included in this study (334-23-1, 38-44 cm and 334-26-1, 18-23 cm) agree well with these earlier findings.

The elastic properties of gabbros also differ significantly from basalts; a difference in compressional wave velocity of about $10 \%$ is found for oceanic gabbros and basalts of similar density (Christensen and Salisbury, 1975). This tendency for compressional wave velocities to increase with increasing grain size in mafic 
TABLE 1

Compressional (P) and Shear (S) Wave Velocities

\begin{tabular}{|c|c|c|c|c|c|c|c|c|c|c|c|}
\hline \multirow{2}{*}{$\begin{array}{c}\text { Sample } \\
\text { (Interval in } \mathrm{cm} \text { ) }\end{array}$} & \multirow{2}{*}{$\begin{array}{l}\text { Bulk } \\
\text { Density }\end{array}$} & \multirow[b]{2}{*}{ Mode } & \multicolumn{9}{|c|}{ Velocity $(\mathrm{km} / \mathrm{sec})$ at Varying Pressures (kbar) } \\
\hline & & & 0.2 & 0.4 & 0.6 & 0.8 & 1.0 & 2.0 & 4.0 & 6.0 & 10.0 \\
\hline $\begin{array}{l}332 \mathrm{~A}-31-3, \\
79-82\end{array}$ & 2.783 & P & 5.59 & 5.67 & 5.71 & 5.74 & 5.76 & 5.85 & 5.95 & 6.03 & 6.18 \\
\hline $\begin{array}{l}\text { 332-A-36-2, } \\
33-36\end{array}$ & 2.183 & $\mathbf{P}$ & 6.06 & 6.09 & 6.12 & 6.15 & 6.17 & 6.26 & 6.34 & 6.39 & 6.46 \\
\hline 332B-3-3, & 2.830 & $\mathbf{P}$ & 6.63 & 6.66 & 6.69 & 6.71 & 6.72 & 6.78 & 6.85 & 6.89 & 6.95 \\
\hline $100-103$ & 2.830 & S & 3.36 & 3.38 & 3.40 & 3.42 & 3.43 & 3.48 & 3.54 & 3.58 & 3.62 \\
\hline $\begin{array}{l}332 \mathrm{~B}-15-1, \\
129-131\end{array}$ & 2.863 & $\mathbf{P}$ & 5.94 & 5.98 & 6.01 & 6.03 & 6.04 & 6.11 & 6.20 & 6.26 & 6.33 \\
\hline 333A-3-1, & 2.802 & $P$ & 5.61 & 5.64 & 5.67 & 5.70 & 5.73 & 5.86 & 5.99 & 6.08 & 6.26 \\
\hline $129-131$ & 2.802 & $\mathrm{~s}$ & 2.88 & 2.94 & 2.98 & 3.02 & 3.05 & 3.15 & 3.24 & 3.27 & 3.29 \\
\hline $334-22-1$, & 3.008 & $P$ & 6.97 & 7.00 & 7.02 & 7.04 & 7.06 & 7.11 & 7.17 & 7.22 & 7.32 \\
\hline $69-71$ & 3.008 & S & 3.56 & 3.58 & 3.60 & 3.63 & 3.65 & 3.72 & 3.78 & 3.82 & 3.87 \\
\hline 334-23-1, & 2.708 & $\mathrm{P}$ & 5.91 & 5.95 & 5.97 & 5.99 & 6.01 & 6.08 & 6.16 & 6.21 & 6.31 \\
\hline $38-44$ & 2.708 & $\mathrm{~S}$ & 2.85 & 2.87 & 2.88 & 2.90 & 2.91 & 2.94 & 2.97 & 2.99 & 3.00 \\
\hline 334-23-1, & 3.006 & $\mathbf{P}$ & 6.96 & 6.99 & 7.01 & 7.02 & 7.04 & 7.09 & 7.16 & 7.21 & 7.31 \\
\hline $135-144$ & 2.995 & $\mathbf{P}$ & 7.05 & 7.08 & 7.10 & 7.12 & 7.14 & 7.20 & 7.28 & 7.34 & 7.43 \\
\hline \multirow[t]{3}{*}{ mean } & 3.001 & $P$ & 7.01 & 7.04 & 7.06 & 7.07 & 7.09 & 7.15 & 7.22 & 7.28 & 7.37 \\
\hline & 3.006 & S & 3.75 & 3.77 & 3.78 & 3.79 & 3.80 & 3.84 & 3.89 & 3.92 & 3.96 \\
\hline & 2.995 & $\mathrm{~S}$ & 3.76 & 3.78 & 3.80 & 3.82 & 3.83 & 3.87 & 3.92 & 3.94 & 3.95 \\
\hline mean & 3.001 & $\mathrm{~S}$ & 3.76 & 3.78 & 3.79 & 3.81 & 3.82 & 3.86 & 3.91 & 3.93 & 3.96 \\
\hline $334-24-1$, & 2.869 & $\mathrm{P}$ & 6.96 & 7.01 & 7.06 & 7.09 & 7.12 & 7.20 & 7.29 & 7.34 & 7.43 \\
\hline $63-65$ & 2.869 & S & 3.52 & 3.54 & 3.57 & 3.59 & 3.60 & 3.66 & 3.73 & 3.76 & 3.80 \\
\hline $334-25-1$, & 2.955 & $\mathrm{P}$ & 6.85 & 6.88 & 6.90 & 6.92 & 6.94 & 6.99 & 7.05 & 7.09 & 7.15 \\
\hline $84-92$ & 2.955 & $\mathrm{~S}$ & 3.61 & 3.63 & 3.64 & 3.66 & 3.67 & 3.70 & 3.72 & 3.74 & 3.76 \\
\hline $334-26-1$, & 2.644 & P & 5.76 & 5.81 & 5.83 & 5.90 & 5.94 & 6.11 & 6.28 & 6.34 & 6.40 \\
\hline $18-23$ & 2.644 & $\mathrm{~S}$ & 2.75 & 2.78 & 2.79 & 2.81 & 2.82 & 2.86 & 2.92 & 2.96 & 3.00 \\
\hline 335-11-1, & 2.830 & $\mathrm{P}$ & 6.11 & 6.14 & 6.16 & 6.18 & 6.20 & 6.26 & 6.33 & 6.38 & 6.46 \\
\hline $76-78$ & 2.830 & $\mathrm{~S}$ & 3.28 & 3.29 & 3.29 & 3.30 & 3.31 & 3.34 & 3.37 & 3.37 & 3.38 \\
\hline
\end{tabular}

rocks was first observed by Birch (1961) in a comparison of gabbro and diabase velocities. Since the influence of porosity on rock velocities is not completely eliminated until hydrostatic pressures in excess of $10 \mathrm{kbar}$ are applied (Christensen, 1974a), the explanation of these differences is apparently related to decreasing grain boundary porosity associated with increasing grain size.

The above relationships between velocity and density also hold for the Leg 37 rocks and are illustrated in Figure 1. The compressional wave velocities of gabbros and serpentinized rocks fall predictably above the basalt data, whereas shear velocities tend to be only slightly higher than oceanic basalts of similar density. Thus, as observed in many earlier studies (Hughes and Maurette, 1957; Birch, 1960, 1961; Simmons, 1964; Christensen and Salisbury, 1975), Poisson's ratios of gabbros tend to be relatively high, usually ranging between 0.30 and 0.32 . Recent velocity measurements in lunar gabbroic anorthosites also show high Poisson's ratios, even though the rocks were not water saturated. Wang et al. (1974) report an average Poisson's ratio of 0.31 for 16 samples of gabbroic anorthosite. It is well known that water saturation increases $V_{\bar{p}}$ much greater than $V_{s}$, thus ratios of $V_{p}$ to $V_{s}$ for these rocks would presumably be even higher if velocities were measured for saturated specimens.

The gabbros included in this study (334-22-1, 69-71 cm; 334-23-1, 135-144 cm; 334-24-1, 63-65 cm; 334-25$1,84-92 \mathrm{~cm}$ ) have Poisson's ratios at oceanic crustal pressures ranging from 0.30 to 0.33 (Table 2), which agree well with previous values for similar rocks. The highest Poisson's ratio ( 0.33 for Sample 334-24-1, 63-65 $\mathrm{cm})$ is a consequence of the relatively high $(\sim 65 \%)$ feldspar content of this rock. Feldspathic rocks have high Poisson's ratios (Birch, 1961), which show a tendency to increase with increasing feldspar content (Christensen and Salisbury, 1975).

\section{OCEANIC CRUSTAL STRUCTURE AND COMPOSITION}

Early studies of oceanic crustal seismic structure by Hill (1957) and a summary of numerous refraction profiles by Raitt (1963) proposed a three-layer model for the oceanic crust which is still generally accepted today. This model consists of a 0.5 to $1 \mathrm{~km}$ layer of sediments overlying a second layer with a relatively well defined thickness (1.0 to $2.5 \mathrm{~km}$ ) and a highly variable compressional wave velocity $(3.5$ to $6.5 \mathrm{~km} / \mathrm{sec})$. Drilling and dredging have shown that layer 2 is usually composed of basalt; its variable velocity most likely is related to weathering, fracturing, intrusion by sills and feeder dikes, and intercalated sediment. Beneath layer 2 and immediately overlying the mantle is layer 3 , a unit of variable thickness (usually 3.4 to $6.3 \mathrm{~km}$ ) and uniform velocity (usually 6.4 to $7.0 \mathrm{~km} / \mathrm{sec}$ ). Recent sonobuoy studies are generally consistent with the earlier studies and often show more detail than the earlier refraction profiles (e.g., Talwani et al., 1971; Sutton et al., 1971). In particular, layer 2 often is found to have a thin, low velocity cap (2.5 to $3.8 \mathrm{~km} / \mathrm{sec}$ ), while layer 3 often contains a basal layer with velocities ranging from 7.1 to $7.7 \mathrm{~km} / \mathrm{sec}$. 
TABLE 2

Elastic Constants, Leg 37

\begin{tabular}{|c|c|c|c|c|c|c|c|c|c|}
\hline $\begin{array}{c}\text { Sample } \\
\text { (Interval in } \mathrm{cm} \text { ) }\end{array}$ & $\begin{array}{l}\text { Pressure } \\
\text { (kbar) }\end{array}$ & $V_{p} / V_{s}$ & $\sigma$ & $\begin{array}{c}\phi \\
(\mathrm{km} / \mathrm{sec})^{2}\end{array}$ & $\begin{array}{c}\mathrm{K} \\
(\mathrm{Mb})\end{array}$ & $\begin{array}{c}\beta \\
\left(\mathrm{Mb}^{-1}\right)\end{array}$ & $\begin{array}{c}\mu \\
(\mathrm{Mb})\end{array}$ & $\begin{array}{c}E \\
(\mathrm{Mb})\end{array}$ & $\begin{array}{c}\lambda \\
(\mathrm{Mb})\end{array}$ \\
\hline 332B-3-3, & 0.4 & 1.97 & 0.33 & 29.11 & 0.82 & 1.21 & 0.32 & 0.86 & 0.61 \\
\hline \multirow{4}{*}{$100-103$} & 1.0 & 1.96 & 0.32 & 29.45 & 0.83 & 1.20 & 0.33 & 0.88 & 0.61 \\
\hline & 2.0 & 1.95 & 0.32 & 29.77 & 0.84 & 1.18 & 0.34 & 0.91 & 0.62 \\
\hline & 6.0 & 1.92 & 0.32 & 30.25 & 0.86 & 1.16 & 0.36 & 0.96 & 0.62 \\
\hline & 10.0 & 1.92 & 0.31 & 30.60 & 0.88 & 1.14 & 0.37 & 0.98 & 0.63 \\
\hline $333 \bar{A}-3-1$, & 0.4 & 1.92 & 0.31 & 20.28 & 0.57 & 1.76 & 0.24 & 0.63 & 0.41 \\
\hline \multirow[t]{4}{*}{$129-131$} & 1.0 & 1.88 & 0.30 & 20.41 & 0.57 & 1.75 & 0.26 & 0.68 & 0.40 \\
\hline & 2.0 & 1.86 & 0.30 & 21.06 & 0.59 & 1.69 & 0.28 & 0.72 & 0.41 \\
\hline & 6.0 & 1.86 & 0.30 & 22.57 & 0.64 & 1.57 & 0.30 & 0.78 & 0.44 \\
\hline & 10.0 & 1.90 & 0.31 & 24.52 & 0.70 & 1.43 & 0.30 & 0.80 & 0.49 \\
\hline $334-22-1$, & 0.4 & 1.96 & 0.32 & 31.90 & 0.96 & 1.04 & 0.39 & 1.02 & 0.70 \\
\hline \multirow[t]{4}{*}{$69-71$} & 1.0 & 1.93 & 0.32 & 32.06 & 0.97 & 1.04 & 0.40 & 1.06 & 0.70 \\
\hline & 2.0 & 1.91 & 0.31 & 32.06 & 0.97 & 1.03 & 0.42 & 1.09 & 0.69 \\
\hline & 6.0 & 1.89 & 0.31 & 32.54 & 0.98 & 1.02 & 0.44 & 1.15 & 0.69 \\
\hline & 10.0 & 1.89 & 0.31 & 33.40 & 1.01 & 0.99 & 0.45 & 1.18 & 0.71 \\
\hline 334-23-1, & 0.4 & 2.07 & 0.35 & 24.41 & 0.66 & 1.51 & 0.22 & 0.60 & 0.51 \\
\hline \multirow[t]{4}{*}{$38-44$} & 1.0 & 2.07 & 0.35 & 24.80 & 0.67 & 1.49 & 0.23 & 0.62 & 0.52 \\
\hline & 2.0 & 2.07 & 0.35 & 25.39 & 0.69 & 1.45 & 0.23 & 0.63 & 0.53 \\
\hline & 6.0 & 2.08 & 0.35 & 26.50 & 0.72 & 1.38 & 0.24 & 0.66 & 0.56 \\
\hline & 10.0 & 2.10 & 0.35 & 27.57 & 0.76 & 1.32 & 0.24 & 0.66 & 0.59 \\
\hline $334-23-1$, & 0.4 & 1.86 & 0.30 & 30.50 & 0.92 & 1.09 & 0.43 & 1.11 & 0.63 \\
\hline \multirow[t]{4}{*}{$135-144$} & 1.0 & 1.86 & 0.30 & 30.79 & 0.92 & 1.08 & 0.44 & 1.14 & 0.63 \\
\hline & 2.0 & 1.85 & 0.29 & 31.21 & 0.94 & 1.07 & 0.45 & 1.16 & 0.64 \\
\hline & 6.0 & 1.85 & 0.29 & 32.27 & 0.97 & 1.03 & 0.46 & 1.20 & 0.66 \\
\hline & 10.0 & 1.86 & 0.30 & 33.19 & 1.01 & 0.99 & 0.47 & 1.22 & 0.69 \\
\hline \multirow{5}{*}{$\begin{array}{l}334-24-1, \\
63-65\end{array}$} & 0.4 & 1.98 & 0.33 & 32.42 & 0.93 & 1.07 & 0.36 & 0.96 & 0.69 \\
\hline & 1.0 & 1.98 & 0.33 & 33.39 & 0.96 & 1.04 & 0.37 & 0.99 & 0.71 \\
\hline & 2.0 & 1.96 & 0.33 & 33.93 & 0.98 & 1.03 & 0.38 & 1.02 & 0.72 \\
\hline & 6.0 & 1.95 & 0.32 & 34.89 & 1.01 & 0.99 & 0.41 & 1.07 & 0.74 \\
\hline & 10.0 & 1.96 & 0.32 & 35.72 & 1.03 & 0.97 & 0.42 & 1.10 & 0.76 \\
\hline $334-25-1$, & 0.4 & 1.89 & 0.31 & 29.76 & 0.88 & 1.14 & 0.39 & 1.02 & 0.62 \\
\hline \multirow[t]{4}{*}{$84-92$} & 1.0 & 1.89 & 0.31 & 30.18 & 0.89 & 1.12 & 0.40 & 1.04 & 0.63 \\
\hline & 2.0 & 1.89 & 0.31 & 30.56 & 0.91 & 1.10 & 0.40 & 1.06 & 0.64 \\
\hline & 6.0 & 1.89 & 0.31 & 31.48 & 0.94 & 1.07 & 0.41 & 1.08 & 0.66 \\
\hline & 10.0 & 1.90 & 0.31 & 32.05 & 0.96 & 1.04 & $\dot{0} .42$ & 1.10 & 0.68 \\
\hline 334-26-1, & 0.4 & 2.09 & 0.35 & 23.44 & 0.62 & 1.61 & 0.20 & 0.55 & 0.48 \\
\hline \multirow[t]{4}{*}{$18-23$} & 1.0 & 2.10 & 0.35 & 24.65 & 0.65 & 1.53 & 0.21 & 0.57 & 0.51 \\
\hline & 2.0 & 2.14 & 0.36 & 26.38 & 0.70 & 1.43 & 0.22 & 0.59 & 0.56 \\
\hline & 6.0 & 2.14 & 0.36 & 28.36 & 0.76 & 1.32 & 0.23 & 0.63 & 0.60 \\
\hline & 10.0 & 2.13 & 0.36 & 28.71 & 0.77 & 1.30 & 0.24 & 0.65 & 0.61 \\
\hline $335-11-1$, & 0.4 & 1.87 & 0.30 & 23.26 & 0.66 & 1.52 & 0.31 & 0.80 & 0.45 \\
\hline \multirow[t]{4}{*}{$76-78$} & 1.0 & 1.87 & 0.30 & 23.81 & 0.67 & 1.48 & 0.31 & 0.81 & 0.47 \\
\hline & 2.0 & 1.87 & 0.30 & 24.27 & 0.69 & 1.45 & 0.32 & 0.82 & 0.48 \\
\hline & 6.0 & 1.89 & 0.31 & 25.42 & 0.73 & 1.38 & 0.32 & 0.84 & 0.51 \\
\hline & 10.0 & 1.91 & 0.31 & 26.27 & 0.75 & 1.33 & 0.32 & 0.85 & 0.54 \\
\hline
\end{tabular}

Studies of the structure, petrology, and physical properties of rocks from ophiolites (Salisbury, 1974; Christensen and Salisbury, 1975) and velocities of rocks dredged from Fracture zones (Christensen, 1974b; Christensen and Salisbury, 1975) have shown that the lower oceanic crust consists of a metamorphic assemblage containing hornblende and plagioclase, which overlies a sequence of late differentiates, which, in turn, grade downward into cumulate gabbro. The hornblende metagabbro occurs within sheeted dikes and has elastic properties similar to those observed for layer 3 from seismic refraction studies $\left(V_{p}=6.5-6.9\right.$ $\mathrm{km} / \mathrm{sec}, \sigma=0.26-0.29$ ). The boundary between layers 2 and 3 does not separate intrusive from extrusive crustal rocks, but instead marks the boundary of a metamorphic front which separates an upper section of chloritized sheeted dikes from similar underlying rocks which contain abundant amphibole (Salisbury, 1974).
Underlying the sheeted dikes are late quartz-rich differentiates which produce velocity inversions within layer 3. The underlying thick section of cumulate gabbros has compressional wave velocities generally ranging between 6.9 and $7.3 \mathrm{~km} / \mathrm{sec}$ and Poisson's ratios of 0.30 to 0.33 .

The velocities and Poisson's ratios of the gabbros recovered from Leg 37 agree well with previous measurements on similar rocks and observations of lower crustal seismic structure. Thus it is possible that the gabbros from Site 334 represent samples of the lower portions of the cumulate section of layer 3 . However, it should be emphasized that the agreement between the laboratory velocity measurements and lower crustal velocities does not prove that these gabbros are samples of the lower oceanic crust. Of significance, it should be noted that between 1 and $3 \mathrm{~km}$ of layer 3 are missing at Site 334, if the gabbros are 


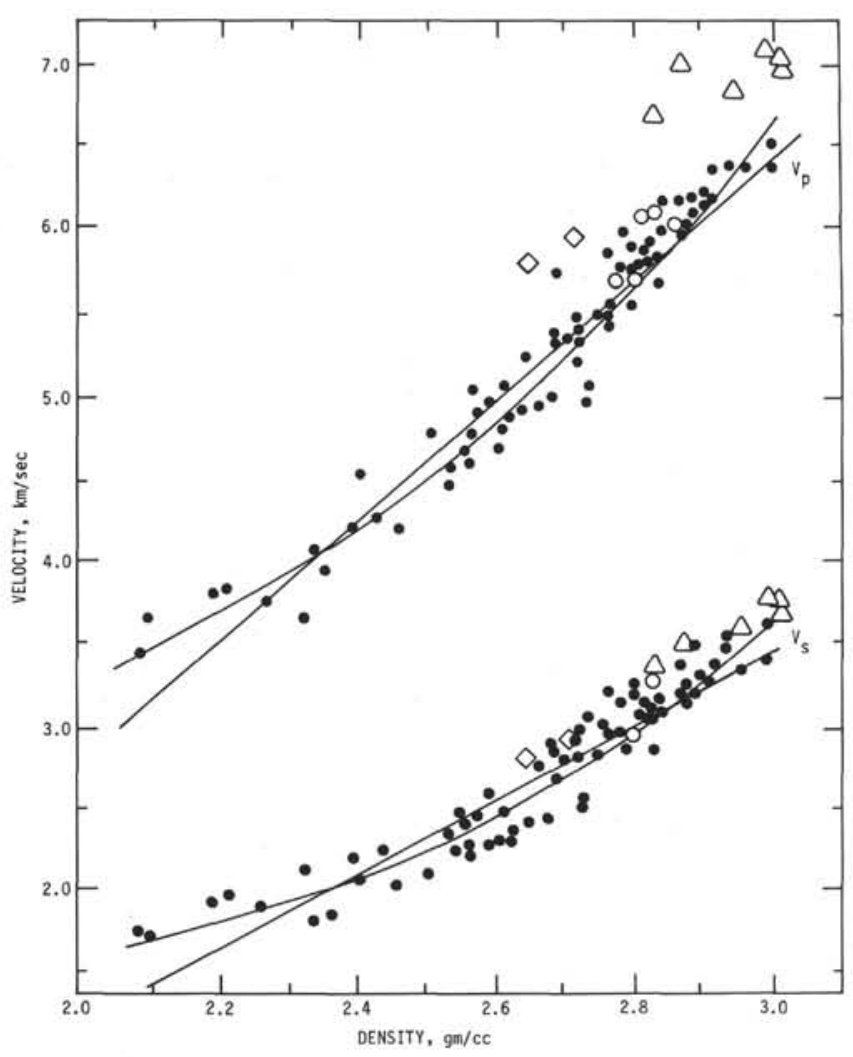

Figure 1. Velocities at $0.5 \mathrm{kbar}$ for previously studied DSDP basalts (solid dots) and Leg 37 basalts (open circles), serpentinized rocks (diamonds), and gabbros (triangles).

lower crustal cumulates. This would require extremely complex tectonic activity to remove thick sections of metagabbro and late differentiates.

Alternate possibilities come to mind to explain the presence of gabbro at shallow crustal depths. Since Site 334 is located near a major fault scarp, the coarsegrained igneous rocks may have been emplaced in upper crustal levels by a mechanism similar to that proposed by van Andel et al. (1969), in which new crust is formed within "leaky" fracture zones. Similar gabbros, which have been dredged from several major fracture zones (e.g., Bonatti et al., 1970; Thompson and Melson, 1972), apparently have originated in this manner. Recently Christensen and Salisbury (1975) have proposed that intermittent off-ridge intrusion fed from underlying anomalous mantle is responsible for the seismic observations of increasing layer 3 thickness away from ridge crests. Even though these gabbroic intrusions usually solidify within the lower levels of layer 3 , it is probable that some reach the upper levels of the oceanic crust and small gabbroic bodies form within layer 2.

\section{ACKNOWLEDGMENTS}

I would like to thank R. Hyndman who provided many of the specimens used in this study. The velocity measurements were made by M. Brown and R.L. Carson. J. Hull helped with the data reduction and tabulation. The research was supported by the Office of Naval Research Contract N00014-67-A-0103-0014.

\section{REFERENCES}

Barrett, D.L. and Aumento, F., 1970. The mid-Atlantic ridge near $45^{\circ} \mathrm{N}$. XI. Seismic velocity, density and layering of the crust: Canadian J. Earth Sci., v. 70, p. 1117-1124.

Birch, F., 1960. The velocity of compressional waves in rocks to 10 kilobars, 1: J. Geophys. Res., v. 65, p. 1083-1102. 1961. The velocity of compressional waves in rocks to 10 kilobars, 2: J. Geophys. Res., v. 66, p. 2199-2224.

Bonatti, E., Honnorez, J., and Ferrara, G., 1970. Equatorial mid-Atlantic ridge: petrologic and $\mathrm{Sr}$ isotope evidence for an alpine type rock assemblage: Earth Planet. Sci. Lett., v. 9 , p. $247-256$.

Christensen, N.I., 1970. Compressional wave velocities in basalts from the Juan de Fuca Ridge: J. Geophys. Res., v. 75 , p. $2773-2775$.

1972. The abundance of serpentinites in the oceanic crust: J. Geol., v. 80 , p. $709-719$.

1974a. Compressional wave velocities in possible mantle rocks to pressures of 30 kilobars: J. Geophys. Res., v. 79 , p. $407-412$.

1974b. The petrologic nature of the lower oceanic crust and upper mantle. In Kristjansson, L. (Ed.), Geodynamics of Iceland and the North Atlantic area: Dordrecht-Holland (D. Reidel Publishing Co.), p. 165176.

Christensen, N.I. and Salisbury, M.H., 1973. Velocities, elastic moduli and weathering-age relations for Pacific Layer 2 basalts: Earth Planet. Sci. Lett., v. 19, p. 461-470. 1975. Structure and constitution of the lower oceanic crust: Rev. Geophys. Space Phys., v. 13, p. 57-86.

Christensen, N.I. and Shaw, G.H., 1970. Elasticity of mafic rocks from the mid-Atlantic ridge: Geophys. J. Roy. Astron. Soc., v. 20, p. 271-284.

Christensen, N.I., Carlson, R.L., Salisbury, M.H., and Fountain, D.M., 1975. Elastic wave velocities in volcanic and plutonic rocks recovered on DSDP Leg 31. In Ingle, J.C., Jr., Karig, D.E., et al., Initial Reports of the Deep Sea Drilling Project, Volume 31: Washington (U.S. Government Printing Office), p. 607-610.

Fox, P.J., Schreiber, E., and Peterson, J.J., 1973. The geology of the oceanic crust: compressional wave velocities of oceanic rocks: J. Geophys. Res., v. 78, p. 5155-5172.

Hill, M.N., 1957. Recent geophysical exploration of the ocean floor: Phys. Chem. Earth, v. 2, p. 129-163.

Hughes, D.S. and Maurette, C., 1957. Variation of elastic wave velocities in basic igneous rocks with pressure and temperature: Geophysics, v. 22, p. 23-31.

Raitt, R.W., 1963. The crustal rocks. In Hill, M.N. (Ed.), The sea, v. 3: New York (Wiley), p. 85-102.

Salisbury, M.H., 1974. Investigation of seismic velocities in the Bay of Islands, Newfoundland ophiolite complex for comparison with oceanic seismic structure: Ph.D. thesis, University of Washington, Seattle.

Simmons, G., 1964. The velocity of shear waves in rocks to 10 kilobars, 1: J. Geophys. Res., v. 69, p. 1123-1130.

Sutton, G.H., Maynard, G.L. and Hussong, D.M., 1971. Widespread occurrence of a high-velocity basal layer in the Pacific crust found with repetitive sources and sonobuoys. In Heacock, J.G. (Ed.), The structure and physical properties of the earth's crust, Geophys. Monogr. Ser., v. 14, Washington (Am. Geophys. Union), p. 193-209. 
Talwani, M., Windisch, C.C., and Langseth, M.G., Jr., 1971. Reykjanes ridge crest: a detailed geophysical study: J. Geophys. Res., v. 76, p. 473-517.

Thompson, G. and Melson, W.G., 1972. The petrology of oceanic crust across fracture zones in the Atlantic Ocean: Evidence of a new kind of sea-floor spreading: J. Geol., v. 80, p. $526-538$. van Andel, T.H., Phillips, J.D., and Von Herzen, R.P., 1969. Rifting origin for the Vema Fracture in the North Atlantic: Earth Planet. Sci. Lett., v. 5, p. 296-300.

Wang, H., Todd, T., Richter, D., and Simmons, G., 1974. Elastic properties of plagioclase aggregates and seismic velocities in the moon: Fourth Lunar Sci. Conf. Proc., Geochim. Cosmochim. Acta, Suppl. 4, v. 3, p. 2663-2671. 